\title{
The current situations and problems of tourist souvenir market on Fuxi culture
}

\author{
Huan Xin ${ }^{1, a}$, Gang Zheng ${ }^{1, b}$ \\ ${ }^{1}$ Lanzhou Institute of Technology, Lanzhou Gansu 730050, China

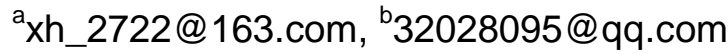

Keywords: Transmission context, Fuxi culture, tourist souvenir.

\begin{abstract}
On the basis of taking full account of the selected and screened requirements for tourism souvenirs on the development of channels and dissemination of information in current communication context, the problems and deficiencies, existing in the exploitation of tourist souvenirs on Fuxi culture, are absolutely understood through the methods of document, investigation and action research at the moment. The influence of different communication channels and transmission objects on the coding mode of transmission information have been studied, and then the tourism souvenirs and their visual expression modes on Fuxi culture have been designed to conform to the modern communication context.
\end{abstract}

\section{Introduction}

With the development of social economy and the improvement of people's living standard, travel has become a common way of leisure for people. Tourists want to buy souvenirs which can reflect characteristics of destination, concentrate regional and folk customs and precipitate memory of travel after the end of the trip. As the material carriers of tourism activities, tourist souvenirs bear the important role of transmitting tourism information and resting emotional memory of the tourist in their place.

\section{Current Domestic Research Situations on Tourist Souvenir on Fuxi Culture}

With environmental issues getting more concentration in the world, the development of tourism industry, an emerging one with lower pollution and higher efficiency, has also been gotten greater attention and support of the governments. In recent years, with the planning and implementation of the economic zone of 'Guanzhong-Tianshui', Chinese academe has gradually strengthened exploration and promotion of the Fuxi culture and the tourism resources in the Tianshui region. Research Association of Chinese Fuxi Culture, established in 2002, has gained more achievements in gathering relative myths and legends, folk stories, archaeological data and audiovisual works of books and periodicals, but the development and promotion of the souvenirs are still not enough in carrying the cultural connotation.

Zhang Xiugui[1], professor from Chinese Historical Geography Research Center of Fudan University, has proved the reasonableness of Fuxi legends existed in Tianshui district and the deep origin of Fuxi culture with the area of Tianshui, and proposed to focus on the use of the unique cultural resources of the Tianshui, to strive to develop the tourism industry of the Tianshui in advantage of Fuxi culture as a breakthrough, and to provide the strategy with 3 principles- 4 aspects. However, in the China International Tourism Commodity Exposition, Gansu province has won the two gold, one silver and eight bronze awards, but there are few tourist souvenirs reflecting Fuxi culture of the Tianshui. In the recent professional works, the article: The Design of Huaian Tourist souvenirs Based Regional Cultural Connotation written by Yang Yang[2], mentioned that the souvenirs only can reflect their cultural values, promote the regional cultural characteristics of the tourist destination and to maximize its value when tourists buy and use them. Another article: Elementary Discussion on The design and Development of Tourist souvenirs in Tianshui of Gansu authored by Shi Ning, proposed 
the concept of innovation on how to mining the characteristics of cultural connotation of Fuxi and brand management. He thought that the iconic symbols, the most representative of the local characteristics, should be transformed into design language of the products development instead of simply reproduced by cultural phenomenon, and looking for the carrier to adapt to the new era and introducing advanced technology and production methods can make the souvenirs rich in modern elements. Famous brand tourism products, with high starting point, high grade and distinctive personality, should be cultivated and exploited through application of new technology and traditional materials or new materials and traditional crafts in the area of Tianshui.

Nowadays, domestic researches generally aware of the cultural connotation and the economic value of tourist souvenirs. From two aspects of the tourist souvenirs market and the development and design, the development strategies of tourist souvenirs, aiming at the purchase behavior, packaging design, and cultural characteristics, etc., have been explored. However, the research works for the development of cultural souvenirs with Fuxi are very few in the view of communication context.

\section{The Problems of Development of Tourist Souvenirs on Fuxi Culture}

\subsection{Inadequate R \& D, Old Style, and Lack of Cultural Connotation and Local Characteristics for}

Tourist Souvenirs. In terms of the bearing items and process types of the souvenirs such as embroidery, clay sculpture, wood carving, carved lacquerware and paper-cut are much various and with highly local characteristics, the development space of culture connotation, the Fuxi culture of Tianshui, is still larger. But at present, the tourist souvenirs on Fuxi culture represent single form, failing to innovate and lacking of modern elements. The tourist souvenirs in the local market, which have been taken from other districts with less than 100 yuan, have no local characteristics and cultural connotation at all. The tourists can't either find satisfactory tourist souvenirs in the medium and lower markets, or afford their high prices of encountered favorite carved lacquerware or carpet goods in silk, and this greatly reduces the desire of tourists shopping.

3.2 Low Quality and No Brand Awareness for Tourist Souvenirs. Most current tourist souvenirs for sale are hard to attract tourists buying them because of lessen alluring appearance and color and rough workmanship. The R \& D of souvenirs about scenic spot is at relatively lower stage and commodity producers are mostly private enterprises that some of them only simply process resources resulting in rough workmanship and poor quality of the souvenirs. Therefore, tourist souvenirs should also have their own brands as well as other commodities and strengthen the brand strategy in the design process.

3.3 Poor Pertinence for Tourist Souvenirs. Nowadays, most successful tourism products, such as carved lacquerware and carpet goods in silk of Tianshui, are high-grade goods with high reputation. The price of these products are about $¥ 300$ or even higher for complex production process and large amount of investment in human and financial resource. The positioning of the consumer population is mainly aimed at high consumers, some even for foreign tourists, instead of low-end consumer.

3.4 Single Sales Channels for Tourist Souvenirs. The sales channels of tourist souvenirs of Tianshui are single without forming mode of organic combination of multi channels. Most sellers have no sense of network sales and no buildup of online sales platforms compared with a few sellers have websites just for advertisement purposes. There are not much online stores in Taobao, Jingdong and other electronic business platforms, reflecting that internet sales haven't been set up yet and business haven’t been operating effectively by professional network marketing team[3].

3.5 Lag of Logistics System and Supporting Service for Tourist Souvenirs. Because of the lack of consideration of commodity packaging and logistics distribution, some tourism products are lessen portability which influents the number of sales: souvenirs, imitation sword of the ancient battlefield, had to make the tourists give up buying due to Chinese relative shipping ban regulations; Guqin with 
carved lacquerware is too large to inconveniently carried which led to poor sales; Behind preservation technologies make some agricultural products and special snacks of Tianshui, peach of Qingan, apple of Huaniu, Guagua and Mianpi, easily decayed on the way backward which also affect the desire of tourists to buying.

3.6 Inadequate Level of R \& D Personnel. At present, Most of the of tourist souvenirs, designed by most design staff in enterprise who have no modern fine arts education, are only the copy of traditional pattern and form or the blunt imitation[4]. Therefore, these designers need to be strengthened with professional training and the design need to improved and optimized according to the modern aesthetic and consumer demand.

\section{Suggestions on Development of Tourist Souvenirs on Fuxi Culture}

4.1 Strengthening the System Construction of $\mathrm{R} \& \mathrm{D}$ Institutions. The R \& D of tourist souvenirs is a systematic project, which include the fundamental theories research, product design, production standard, processing technic, Material selection, manufacturing management, market circulation, publicity and marketing, developer cultivation, personnel training and development evaluation, etc.

Corresponding policies should be formulated for supporting and encouraging relevant research and development institutions to set up in enterprises or universities. Given full play to the advantages of college intelligence, the corresponding research subjects need to be established to study how to strengthen basic research and development design, find typical regional culture and study on the characteristics and image of cultural landscape. Through strengthen the cooperation of production, learning and research, professional researchers related to tourism, art design, history and culture have been able to play their full role and to mobilize the enthusiasm of the R \& D of tourist souvenirs. On the basis of the R \& D platform construction of tourist souvenirs, the cooperation both the enterprises of R \& D of tourist souvenirs and universities and interdisciplines should be encouraged so as to realizing the integration of talent and resources, optimizing $\mathrm{R} \& \mathrm{D}$ team and enhancing $\mathrm{R} \& \mathrm{D}$ capabilities and level.

4.2 Building a Strong Brand. To highlight the advantages and further establish the famous brand and the trademark awareness, the enterprises need to be actively guided to improve marketing strategies, cultivate special products and enhance the strength of the development of special economic. Through improving the brand concept and strengthening the brand culture, the gradually increasing cultural products with famous brand and more competition can be built and recognized by the market. On the one hand, to strengthen the protection of existing brand tourist souvenirs, traditional craft and heritage, a strong brand can be built through the innovation of technology and management and the innovation of packaging design to improve quality and reputation. On the other hand, to strive to build R \& D bases of tourist souvenirs, vigorously support the new enterprises and actively cultivate more local brands, the new generation of brand will be made through the innovation of products, packaging and service and powerful means of marketing to enhance market visibility and reputation.

4.3 Focusing on Multi-channel Integrated Sales. Though the sales model is independent of the enterprise, the channel management is very important for the enterprise's management and development. The establishment of sales channels enables the products to have market sales experience and marketing network across the country in the early days of the market that can strengthen intensity distribution and improve the speed of enterprise capital turnover. Enterprises should be based on product characteristics and sales target position to develop their own sales channels, but also can establish a full range of multi-channel marketing. With a great boom of the internet era, the means of information from spreading has been changed to promote the sales channels changed dramatically. The traditional marketing channel with single function is just a pass from the producer to the consumer, and the consumer can only obtain the commodity information from the 
mass media. Since the rapid development of new we-medias such as WeChat, micro-blog, social media, etc. [5], in modern society, the combined mode of online and offline can be adopted to increase the brand propagandist strength of tourist souvenirs and the 'Internet Plus' thinking mode should be fully used to broaden the sales of new channels.

\section{Summary}

The development and growth of tourism culture industry, known as 'the eternal sunrise industry', is one of the important signs of the comprehensive strength of the region which can promote the rapid and healthy development of local economy and reflect the development trend of local economic, social and culture. Given sales revenue of tourist souvenirs is an important component of the tourism industry and the R \& D level of them reflects the depth and breadth of the development of tourism, to develop the tourist souvenirs on Fuxi culture is the only way of the tourism industry in the Tianshui area.

First, the problems and shortages of the market of tourist souvenirs on Fuxi culture have been studied in current transmission context, and then the strategies and suggestions for the effective communication of symbols of Fuxi culture are put forward, meanwhile the visual elements with typical regional characteristics and symbols of Fuxi culture are refined and some samples of tourist souvenirs on Fuxi culture are designed according to the requirement of the communication elements. Through the systematic research of the project, the development ways of tourist souvenirs on Fuxi culture have been expanded and the cultural communications of tourist souvenirs on Fuxi culture have been improved effectively. These provide some theoretical support for the transmission of Fuxi culture and the establishment of cultural strategy platform, which is based on construction of demonstration zone on Chinese civilization protection heritage and innovation development.

\section{Acknowledgment}

The authors gratefully acknowledge financial supports from National Social Science Fund Project (No.15XMZ035), Gansu Research Project in Colleges and Universities (No.2013B-99, No.2013A-130), Lanzhou Science and Technology Development Project (No.2015-3-30).

\section{References}

[1]G.X. Zhan, Fuxi Culture and Exploitation of Tourism Resources in Tianshui, Journal of Tianshui Normal University. 22 (2002) 49-52.

[2]N. Shi. The Design and Development of Tourist Souvenirs in Gansu, Journal of Tianshui Art and Literature. 07(2012)287.

[3]J. Hou, Design Research of Tourism Commodity in Tianshui. Hebei University of Science and Technology. 2015

[4]S.Y. Wei, On the Effective Communication of Visual Communication Design,The Press. 12 (2014) 148-149

[5]H.Y. Zhou, A Study of the Development of Tourist Souvenir Based on 4C Theory, Journal of Anhui Agricultural University (social science edition).19 (2010) 49-52 